\title{
Actin, Gamma-Enteric Smooth Muscle
}

National Cancer Institute

\section{Source}

National Cancer Institute. Actin, Gamma-Enteric Smooth Muscle. NCI Thesaurus. Code C30011.

Actin, gamma-enteric smooth muscle (376 aa, $\sim 42 \mathrm{kDa}$ ) is encoded by the human ACT G2 gene. This protein plays a role in the cytoskelton and cell motility. 